Pinisi Discretion Review

Volume 4, Issue 2, March 2021 Page. 203- 210

ISSN (Print): 2580-1309 and ISSN (Online): 2580-1317

\title{
Analysis of Factors Affecting the Results Student Learning in Accounting Students Accounting Expertise Program
}

\author{
M. Yusuf A. Ngampo \\ Accounting Education Study Program, Faculty of Economics, \\ Universitas Negeri Makassar \\ Email: yusufngampo@gmail.com
}

(Received: January-2021; Reviewed: February-2021; Accepted: February-2021;

Avalaible Online: February-2021; Published: February-2021)

This is an open access article distributed under the Creative Commons Attribution License

CC-BY-NC-4.0 (2021 by author (https://creativecommons.org/licenses/by-nc/4.0/)

\begin{abstract}
The research is aimed to determine the factors of interest in learning, and learning disciplines that affect student learning outcomes accounting expertise. This type of research is qualitative research using qualitative descriptive analysis tools and multiple regression analysis to determine how much these factors influence. The sample is 76 students using proportional random sampling technique. This study means that the interest variable (X1) has a positive effect on learning outcomes (Y). This indicates that if the interest variable increases one unit, while the student learning discipline variable is considered constant it will cause an increase in learning outcomes by 0.480 . This indicates that when the learning discipline variable has increased by one unit and the interest variable is considered constant it will cause an increase in learning outcomes. learning outcomes of 0.477 . The results of the correlation coefficient analysis obtained a value (r) of 0.640 , which means that the relationship between student learning outcomes and student learning interest and student learning discipline is in the strong category. Where the correlation value is in the coefficient interval $0.60-0.799$. While the coefficient of determination (r2) is 0.410 or 41 percent, which means that the effect of student interest in learning and learning discipline on student learning outcomes is 41 percent, while the remaining 59 percent $(100 \%-\mathrm{r} 2)$ is determined by other factors not included in this study. The results of the t-test show that the significant value is smaller than the alpha value, where the significant value $=0.002<$ alpha $=0.05$, which means that it is significant, so the hypothesis proposed is that: "It is assumed that interest in learning and student learning discipline has a significant effect on learning outcomes. students in the Accounting Skills Program of SMK Negeri 1 Pangkep are declared "accepted".
\end{abstract}

Keywords: Factors of interest in learning; learning discipline; student learning outcomes 


\section{INTRODUCTION}

The competition experienced by Vocational High School / Madrasah Aliah (SMK / MAK) graduates or in winning job opportunities is getting tighter (Darwis et al., 2019; Nasrullah et al., 2017). Only those who are competent are able to win the competition. Especially in facing the global market, where workers from any country will be free to compete in our country. In line with these conditions, SMK / MAK must be increasingly prepared to equip their graduates with the competencies needed by the world of work so that graduates can truly compete and be ready to win them (Niswaty et al., 2017; Rengifurwarin et al., 2018; Saggaf, Salam, \& Rifka, 2017).

The main objective of SMK / MAK is to prepare graduates who are ready to work in their fields. In connection with the preparation of this workforce, it is explicitly stated in Government Regulation No. 29 of 1990 on market 29 paragraph 2, that: "to prepare Vocational School students to become workers, at SMK a Production Unit which operates professionally can be established". For this reason, SMK must be able to provide learning experiences to students in order to master productive competencies professionally. The rapid development of science and technology today is a very big challenge for the world of education in our country. Education is an absolute thing for every human being and cannot be separated from personal life, family and nation and State. Through education will be formed personal with quality as expected by the purpose of education itself.

The general objective of national education is to educate the nation's life and develop Indonesian people as a whole, namely people who believe and have faith in God Almighty and have noble character, have knowledge and skills, physical and spiritual health, solid and independent personality and a sense of social responsibility and nationality. National education functions to develop capabilities and shape the character and civilization of a nation with dignity in the framework of educating the nation's life, aiming at developing the potential of students to become human beings who believe and have devotion to God Almighty, noble, healthy, knowledgeable, capable, creative, independent and become a democratic and responsible citizen.

Educational goals will be achieved if student learning outcomes experience development and improvement and are able to shape behavior in accordance with educational goals. Learning outcomes in learning are very important because the success of learning carried out in teaching and learning activities can be seen from student learning outcomes. Interest has a very big influence on learning outcomes, because if the lessons learned are not in accordance with their interests, students will not learn well because they do not interest them. Students will be lazy to learn and do not get satisfaction from the lesson.

In addition, a factor that affects learning outcomes is discipline (Farida et al., 2015; Jufri et al., 2018; Souisa et al., 2019). Discipline is one of the internal factors that affect student learning outcomes. Discipline is also a means of education. In educating discipline, it plays a role in influencing, encouraging, controlling, changing, fostering and shaping certain behaviors in accordance with the values instilled, taught and modeled. Therefore, changes in a person's behavior include learning outcomes from a planned, informal or self-taught educational and learning process.

Discipline is an order that gives order to personal and group life. Discipline arises from within the soul, because of the urge to obey these rules. In learning discipline is very necessary because discipline will give birth to the spirit of respecting time, not wasting time passing in a vacuum. One of the things that underlie student learning discipline is the emergence of students' awareness to want to carry out and complete their learning tasks properly, according to their responsibilities as students (Jufri et al., 2018; Niswaty et al., 2017; Saggaf, Salam, \& Wirawan, 2017; Salam et al., 2018). 
In order to increase the discipline and sense of responsibility of students at school, a teacher must state the rules and their consequences, if students break them these consequences are carried out gradually, starting with warnings, admonitions, giving a check mark, being asked to face the principal, or reporting to their parents about the violation he did at school.

SMK Negeri 1 Pangkep is a school under the South Sulawesi Provincial Education Office. This school applies the 2013 curriculum. The following is presented data on interest and learning discipline obtained using a questionnaire of 20 question items using the Likers scale measurement with a total score of 100 on 4 respondents as initial data.

That the first respondent has very good interests and excellent learning outcomes. The second respondent has poor interests and poor learning outcomes. This shows that when interest is very good, learning outcomes are very good. Conversely, if the interest is not good, the learning outcomes are not good. So, it can be concluded that interest has a positive effect on learning outcomes. This is in line with research conducted by Salam et al.(2018) which states that there is a positive and significant effect of interest on learning outcomes.

Unlike the case with the third respondent who has poor interest and very good learning outcomes. The fourth respondent has good interest and poor learning outcomes. This shows that when interest is not good, learning outcomes are very good. Conversely, if the interest is good, the learning outcomes are not good. So, it can be concluded that interest has a negative effect on learning outcomes. This is not in line with research conducted by Salam et al.(2018) which states that there is a positive and significant influence of interest in learning outcomes.

First responders have excellent learning discipline and excellent learning outcomes. The second respondent has poor learning discipline and poor learning outcomes. This shows that when the discipline of learning is very good, the learning outcomes obtained are very good. Conversely, if the learning discipline is not good, the learning outcomes obtained are not good. This is in line with research conducted by Salam et al.(2018) which states that there is a positive and significant influence on learning discipline on learning outcomes.

Unlike the case with the third respondent who has poor learning discipline and very good learning outcomes. The fourth respondent has very good discipline and poor learning outcomes. This shows that when the learning discipline is not good, the learning outcomes are very good. Conversely, if the discipline of learning is very good, the learning outcomes are not good. So, it can be concluded that learning discipline has a negative effect on learning outcomes. This is not in line with research conducted by Salam et al.(2018) which states that there is a positive and significant influence on learning discipline on learning outcomes.

\section{METHOD}

The population and sample in this study were students of SMK Negeri I Pangkep Accounting Skills Program, which amounted to 319 with 139 men and 180 women consisting of 9 classes, the number of samples to be studied was 76 students. determined by proportional random sampling. Types and sources of data used in this study are the types of data used in this paper are; 1) Qualitative data, namely data in the form of written information, namely regarding teachers, students, facilities and infrastructure, curriculum, syllabus, and learning tools; 2) Quantitative data, namely data obtained in the form of student learning outcomes in accounting subjects and vocational competency subjects.

Sources of data to be analyzed in this study are: 1) Primary data, namely data obtained through direct observation and interviews with respondents; 2) Secondary data, namely data obtained from documents and other sources related to this research, in the form of information about the background of students and information about teachers, learning media tools, facilities and infrastructure, curriculum, time, materials teach as well as students through questionnaires (Creswell \& Creswell, 2017). 
The data analysis used was analysis; 1) Test data quality consisting of; validity test and data reliability test where the commitment to measure and test a questionnaire or hypothesis is highly dependent on the quality of the data used in the test. Research data will not be useful if the instruments used to collect research data do not have reliability (level of reliability) and validity (high level of truth / validity). These measurement tests each demonstrate the consistency and accuracy of the data collected. And 2) Hypothesis testing where to prove the proposed hypothesis, inferential statistical analysis is used as follows: a) Significance test of multiple linear regression coefficients; b) Analysis of the correlation coefficient; and c) T test.

\section{RESULT AND DISCUSSION}

Accounting learning outcome data, it can be seen the categorization of the value achieved by students. This categorization uses the minimum completeness criteria value set by the accounting subject teacher at SMK Negeri 1 Pangkep, which is $\geq 75$, so students can be said to be complete in their learning, while $<75$, students can be said to be incomplete in their learning.

The results of the descriptive analysis of student learning outcomes show that the average value (mean) is 83.86 which is in the interval 83 - 91. Based on the description it can be concluded that the variable learning outcomes of students in SMK Negeri 1 Pangkep are included in the "good" category which means complete. . Even so, there are still 21 students who have learning outcomes below the average.

Description of interest variable data is based on data obtained from distributing questionnaires to three classes of accounting expertise program with a total sample size of 76 respondents with three indicators, namely 1) Motivation or motivation to learn, 2) Student participation in teaching and learning activities, 3) Attention of students in activities learn how to teach.

The results of the research on interest illustrated the percentage of the total score of all respondents' answers obtained from 3 indicators, namely motivation or encouragement to learn, student participation in teaching and learning activities, student attention in teaching and learning activities. shows the percentage of interest variable data with the results of the percentage of the actual overall score of 74.44 percent which is classified as good. Even so, there are still components that are below the actual score, namely student participation in teaching and learning activities. With an actual score of 73.25 percent, this is because students lack the initiative to ask questions when having difficulty understanding accounting material.

The data description of the learning discipline variable is based on data obtained from distributing questionnaires to students of accounting expertise program with a total sample of 76 respondents with five indicators, namely 1) Adjusting the learning time at home, 2) Regularly studying, 3) Attention in class, 4) Orderliness in class, 5) The value achieved by students.

The results of the study were the percentage data of the learning discipline variable with the percentage of the actual overall score of 83.94 percent which was classified as good. Even so, there are still components that are below the actual score, namely managing study time at home. With an actual score of 79.16 percent, this is because students spend more time relaxing at home. And indicators that are below the actual score are diligent regularly studying with an actual score of 83.15 percent, this is because students are more concerned with organization or personal affairs.

An instrument is declared valid if the correlation coefficient $r$ table is at a significance level of 1 percent or 5 percent. Test the validity of the instrument by looking at the correlation coefficient ( $\left.r \_x y\right)$ which states the relationship between the statement instrument scores and the total score (item-total correlation). Based on the results obtained in table 5.9, from testing the validity of the research instrument, it shows that all items of statement $X 1$ have a value of $r$ 
count 0.281-0.520 and in the questionnaire have item total correlation or $r$ table $>0.250$. Based on these results, it can be concluded that all items of question X1 in the questionnaire are valid.

Meanwhile, of all statement items X2 has a value of $r$ count $0.259-0.533$ and in the questionnaire it has item total correlation or $r$ table $>0.250$. Based on these results, it can be concluded that all items of question $\mathrm{X} 2$ in the questionnaire are valid.

A research instrument is declared reliable if the Cronbach's Alpha value is $>0.60$. The reliability test in the study was conducted using the Cronbach's Alpha technique, with a sample size of the $\mathrm{X}$ and $\mathrm{Y}$ variables, namely 76 respondents. Based on table 5.10, the results of the research instrument reliability test showed that cronbach's alpha> 0.60 , from the X1 research results, showed that cronbach's alpha was 0.605 , so it could be concluded that the instrument was declared reliable. Meanwhile, from the X2 research results, showing Cronbach's alpha 0.609 , it can be concluded that the instrument is declared reliable.

Based on the results of the data quality test analysis, it can be concluded that the instrument test which includes the validity test and the reliability test, states that all items in this study are valid and all of the research variables are declared reliable. Meanwhile, the results of the normality test using the P-Plot graph test show that the points are close to each other, meaning that the analyzed data is normally distributed.

The multicollinearity test results showed the value of Variance Inflation Factor (VIF) for the interest variable of 1.646 and learning discipline of 1.646 . These two variables are smaller than 10 , meaning that there is no multicollinearity to the data being tested. The tolerance value for the interest variable is 0.607 and the student learning discipline variable is 0.607. Because the tolerance value of the two variables is greater than 0.10 , it means that there is no multicolonierity to the data being tested.

The autocorrelation test results show the Durbin-Watson statistical value (d) of 1.690. The lower limit value ( $\mathrm{dl}$ ) and the upper limit value (du) with $\alpha=5 \%$ at $\mathrm{n}=76$ and $\mathrm{k}=2$, then the du value is 1.6819. Durbin Watson's score of 1.690 is more than the limit (du) ie, 1.6819 and less than $4(\mathrm{du}) 4-1.6819=2.3181$. The calculated Durbin Watson value lies in the area between the values of $\mathrm{du}<\mathrm{d}<4$-du which means there is no autocorrelation, positive or negative. Thus, in this regression model there is no autocorrelation. While the results of the heteroscedasticity test show that there is no certain pattern and the points spread above and below the number 0 on the $\mathrm{Y}$ axis, so it can be concluded that heteroscedasticity does not occur.

Based on the results of the multiple linear regression equation analysis, the two independent variables, namely interest and learning discipline, have significant profitability 0.02 and 0.05 , respectively. Therefore, it can be concluded that the learning outcome variable is influenced by student interest and learning discipline. The following is a multiple regression equation.

The explanation of the regression equation:

$$
Y=27,378+0,480 X_{1}+0,477 X_{2}
$$

The constant of 27.378 shows that if the variables of interest and learning discipline are considered equal to 0 , then the learning outcome variable is 27.378 .

The Interest Coefficient (b_1 X_1) $=0.480$ in this study means that the interest variable (X_1) has a positive effect on learning outcomes (Y). This shows that if the interest variable has increased by one unit, while the student learning discipline variable is considered constant, it will cause an increase in learning outcomes of 0.480 .

Learning Discipline Coefficient (b_2 X_2) $=0.477$ in this study it means that the student learning discipline variable (X_2) has a positive effect on learning outcomes (Y). This shows that when the learning discipline variable has increased by one unit and the interest variable is considered constant, it will cause an increase in learning outcomes of 0.477 . 
Furthermore, to test the hypothesis, the $\mathrm{F}$ test is carried out to determine the effect of interest and learning discipline on learning outcomes together or simultaneously. Data processing was performed using SPSS v.25 for windows. The result shows that the significance level value is $0.00<0.05$. So it can be concluded that the hypothesis is accepted, or in other words, interest and learning discipline have a simultaneous effect on the learning outcomes of students in the accounting expertise program at SMK Negeri 1 Pangkep, Pangkep Regency.

Furthermore, analysis of the coefficient of determination $\left(\mathrm{r}^{\wedge} 2\right)$ was obtained a value of 0.410. This means that the influence of interest and learning discipline is 41 percent and the remaining 59 percent is influenced by other factors that influence the determination of the increase or decrease in student learning outcomes because apart from interest and learning discipline there are many other factors that are not examined.

Adjusted R square is a coefficient of determination that has been correlated with the number of variables and samples so that it can reduce the element of bias if there are additional variables. Adjusted R square value of 0.394 means that the variation of student learning outcomes variables can be explained by the interest and learning discipline variables by 39.4 percent, or the interest and learning discipline variables have an effect on student learning outcomes by 39.4 percent.

Based on the results of the research that has been done, the results show that interest (X_1) and learning discipline (X_2) simultaneously have a significant effect on the learning outcomes of students in the accounting expertise program at SMK Negeri 1 Pangkep with a significant level of $0.000<0.005$. The results of this study are in line with research conducted by Megawati (2015) which states that interest and learning discipline affect student learning outcomes.

The results of this study imply that the higher the interest in learning and the better the learning discipline that is applied in school, it will make a good and positive contribution to the achievement of student learning outcomes. Where interest in learning is measured based on three indicators, namely; 1) Motivation or encouragement to learn, 2) Participation of students in teaching and learning activities, 3) Attention of students in teaching and learning activities. The three indicators show good results. So in the learning process students must have an interest or liking to take part in the learning activities that are taking place, because interest will encourage students to show concern, activity and participation in the ongoing learning.

While learning discipline is measured based on five indicators, namely; 1) Adjusting the study time at home, 2) Regularly studying, 3) Attention in class, 4) Orderliness in class, 5) The scores achieved by students, and the five measured indicators show good results. This is in line with the opinion that being disciplined in addition to making a student have skills regarding good learning methods, it is also a process towards forming a good character and a noble personality. Order and discipline must be instilled and developed with full will and seriousness. By having good habits, every effort to learn will always give very satisfying results. In addition, with discipline, students can control the desired behavior so that school assignments can run optimally. With discipline it is also expected that students are willing to obey and follow certain rules and stay away from certain restrictions as well (Gan et al., 2015; Pina et al., 2015; Waugh \& Donaldson, 2016).

This means that interest and learning discipline play an important role in improving student learning outcomes. If the interest and discipline of learning is high, student learning outcomes will improve so that the desired goal can also be achieved, namely to improve the quality of education. 


\section{CONCLUSION}

The results of descriptive data analysis showed that the student interest factor at SMK Negeri 1 Pangkep from the three indicators analyzed showed that the results were in the good category, and the students' interest in the Accounting Skills Program from the three indicators measured in the very good category. Meanwhile, the learning discipline in the five indicators of measuring time at home is the lowest component of the percentage score. And the highest component in the indicator of learning discipline is the value achieved by students. Based on the conclusions that have been put forward regarding "Analysis of Factors Affecting Student Learning Outcomes in Accounting Subjects in the Accounting Expertise Program at SMK Negeri 1 Pangkep".

\section{REFERENCES}

Creswell, J. W., \& Creswell, J. D. (2017). Research design: Qualitative, quantitative, and mixed methods approaches. Sage publications.

Darwis, M., Batari, U. D., Salam, R., Kasmita, M., \& Baharuddin, A. (2019). Pengaruh Kompetensi Profesional Guru Terhadap Kualitas Proses Pembelajaran Pada Paket Keahlian Administrasi Perkantoran Di SMK Negeri 1 Gowa. Jurnal Ad'ministrare: Jurnal Pemikiran Ilmiah dan Pendidikan Administrasi Perkantoran, 5(2), 105-112.

Farida, U., Akib, H., \& Jasruddin. (2015). Policy implementation of the national program for community empowerment in rural areas healthy and intelligent generation in Mamuju regency of West Sulawesi, Indonesia. International Journal of Economic Research, 12(5).

Gan, B., Menkhoff, T., \& Smith, R. (2015). Enhancing students' learning process through interactive digital media: New opportunities for collaborative learning. Computers in Human Behavior, 51, 652-663. https://doi.org/https://doi.org/10.1016/j.chb.2014.12.048

Jufri, M., Akib, H., Ridjal, S., Sahabuddin, R., \& Said, F. (2018). Improving attitudes and entrepreneurial behaviour of students based on family environment factors at vocational high school in Makassar. Journal of Entrepreneurship Education, 21(2).

Nasrullah, M., Rumingan, M., Nasaruddin, N., \& Niswaty, R. (2017). Pengaruh Pengambilan Keputusan Kepala Sekolah terhadap Kinerja Guru di SMK Negeri 1 Makassar. Jurnal Ad'ministrare, 4(2), 103-110.

Niswaty, R., Rusbiati, S., Jamaluddin, J., \& Salam, R. (2017). The Influence of Teacher's Reinforcement for Students Motivation. International Conference on Education, Science, Art and Technology, 148-152.

Pina, R., Cabral, I., \& Alves, J. M. (2015). Principal's Leadership on Students' outcomes. Procedia - Social and Behavioral Sciences, 197, 949-954. https://doi.org/https://doi.org/10.1016/j.sbspro.2015.07.279

Rengifurwarin, Z. A., Akib, H., Jasruddin, \& Salam, R. (2018). Snapshot of public service quality in the center for integrated business service (CIBS), cooperative micro small and medium enterprises (CMSME), Maluku province, Indonesia. Journal of Entrepreneurship Education, 21(3).

Saggaf, M. S., Salam, R., \& Rifka, R. (2017). The Effect of Classroom Management on Student Learning Outcomes. International Conference on Education, Science, Art and Technology, 98-102.

Saggaf, M. S., Salam, R., \& Wirawan, H. (2017). The Influence of Teacher's Pedagogic Competence on Learning Motivation of Student of Office Administration Expertise Package. 8th International Conference of Asian Association of Indigenous and Cultural Psychology (ICAAIP 2017).

Salam, R., Akib, H., \& Daraba, D. (2018). Utilization of Learning Media In Motivating Student 
210 Pinisi Discretion Review

Volume 4, Issue 2, March 2021 Page. 203- 210

Learning. 1st International Conference on Social Sciences (ICSS 2018).

Souisa, W., Musa, C. I., Akib, H., Anshari, \& Bado, B. (2019). Determinats of the performance of cooperative manager in ambon city, indonesia. Journal of Entrepreneurship Education, 22(1).

Waugh, A., \& Donaldson, J. (2016). Students' perceptions of digital narratives of compassionate care. Nurse Education in Practice, 17, 22-29. https://doi.org/https://doi.org/10.1016/j.nepr.2016.01.008 